\title{
Capital Structure Adjustments and Asymmetric Information
}

\author{
Alexandre Ripamonti ${ }^{1}$ \\ ${ }^{1}$ Graduate Program in Management, Ibirapuera University, Sao Paulo, Brazil \\ Correspondence: Alexandre Ripamonti, Graduate Program in Management, Ibirapuera University, Sao Paulo, SP., \\ 04661-100, Brazil. Tel: 55-11-5694-7984. E-mail: alexandre.ripamonti@ibirapuera.edu.br
}

Received: October 7, 2019

Accepted: October 30, $2019 \quad$ Online Published: November 5, 2019

doi:10.5539/ijef.v11n12p1

URL: https://doi.org/10.5539/ijef.v11n12p1

\begin{abstract}
The findings of this paper suggest another reason for capital structure adjustments besides the Trade-Off and Pecking Order theories propositions because asymmetric information impacts capital structure changes and deviations only for a quarter whilst stationarity impacts them for 4 quarters, even when controlled. Asymmetric information has been measured by Corwin-Schultz bid ask spread estimator and capital structure target as the mean of debt-to-equity ratio of 262 Nyse non-financial and non-regulated companies and their industries during 91 quarters. The data were analyzed with Johansen-Fisher panel cointegration. The capital structure deviations last from 2 to 4 quarters and move toward a target.
\end{abstract}

Keywords: capital structure adjustments, Corwin-Schultz bid-ask spread estimator, asymmetric information, Johansen-Fisher panel cointegration, dynamic trade-off theory, market microstructure

\section{Introduction}

\subsection{The Problem}

The seminal works on capital structure (Modigliani \& Miller, 1958; 1963; Myers \& Majluf, 1984), optimal capital ownership structure (Jensen \& Meckling, 1976), and stock market development (Demirgüc-Kunt \& Maksimovic, 1996) that state the difference in quality and quantity of information among managers, investors, and informed and uninformed traders (Akerlof, 1970), have developed relevant roles in capital structure theories, either as an extremely rigid assumption of a perfect market or following hierarchical choices and tax shield issues.

In capital structure adjustments (Leary \& Roberts, 2005; Dang \& Garret, 2015), asymmetric information has been studied as an important variable of capital structure adjustment toward its target (Byoun, 2008; Faulkender, Flannery, Hankins, \& Smith, 2012; Dang, Kim, \& Shin, 2014).

However, there could be a void in studying capital structure adjustments with the use of a specific asymmetric information measure (Andres, Cumming, Karabiber, \& Schweizer, 2014) beyond its effects, or proxies of differences of adjustment toward a target (Byoun, 2008; Dang \& Garret, 2015).

Considering this, the study of microstructure market theory (Hasbrouck, 1988; 1991; 2007) was undertaken that lead to the development of certain measures of asymmetric information (Roll, 1984; Easley \& O'Hara, 1991), which were related to several relevant finance subjects (Easley, O’Hara, \& Srinivas, 1998; Easley, Hvidkjaer, \& O'Hara, 2002; Easley \& O'Hara, 2004). Among such measures, the private information PIN Score (Easley, Hvidkjaer, \& O'Hara, 2002) is a standard in literature, though it is occasionally restricted by the availability of intraday data and high computational challenges.

As alternative to this standard, there is the high-low bid-ask spread estimator of Corwin-Schultz, a consistent and validated measure that simplifies the asymmetric information measurement (Corwin \& Schultz, 2012a; 2012b) and has been studied in several methods (Maskara \& Mullineaux, 2011; Lin, 2014; Zhang, Yang, Su, \& Zhang, 2014; Cerqueira \& Pereira, 2014; Ripamonti, 2016) using companies' data of the United States of America (the U.S.) for the period 1926 to 2014 (Corwin \& Schultz, 2012b).

The aim of this study is to examine capital structure adjustments using an asymmetric information measure, supposing that higher asymmetric information leads to a lower capital structure speed of adjustment (Modigliani \& Miller, 1963). This hypothesis is based on the assumption that asymmetric information represents additional adjustment costs (Devos, Rahman, \& Tsang, 2017) to the bond or stock markets. 
In order to prevail over the effects of the stock market developments (Demirgüc-Kunt \& Maksimovic, 1996; Demirgüc-Kunt, Feyen, \& Levine, 2013), the sample is selected from the most liquid shares of non-financial and non-regulated NYSE companies, during a stipulated period of time, the data for which could be consistently examined (Johansen, 1988; Johansen, 1991) and controlled for the main determinants of capital structure (Titman \& Wessels, 1988).

\subsection{Theoretical Framework}

\subsubsection{Capital Structure Adjustments}

Several tests have been conducted on capital structure target and its behaviour, subsequent to Modigliani and Miller (1963). The biases of adjustment costs, macroeconomic conditions, and econometric estimation were found as the main determinants of capital structure speed of adjustments.

Leary and Roberts (2005) found that capital structure adjustments significantly depend on costs, when compared to other variables. Similarly, Byoun (2008) observed that the existence of asymmetric information costs influence companies to adjust their leverage toward the target, and this influence is stronger when companies face a financial surplus or deficit, when the costs of issuing debt or stock rise or fall, as preconized by the pecking order theory.

DeAngelo, DeAngelo, and Whited (2011) found that the evolution of leverage reflects the sequence of investment outlays through a dynamic model which would replicate industry leverage better than other trade-off models. Dang, Kim, and Shin (2012) found that companies with large financing imbalances or investments, or low earnings volatility have a significantly faster adjustment speed toward heterogeneous leverage targets, considering that there are differential adjustment costs or asymmetric adjustments, depending on the firm's characteristics. In addition, they developed a dynamic panel threshold model with the estimation approach combining time-series techniques and advanced methods for dynamic panels.

Faulkender et al. (2012) mixed the effects of transaction costs and cash flow generation, and found that firms that generate larger cash flows have greater adjustment speeds. Dang, Kim, and Shin (2014) also documented that companies with high growth, large investments, small size, and volatile earnings reached higher speeds of adjustment of capital structure probably due to the lower adjustment costs that are shared with the transaction costs of accessing external capital markets. Lockhart (2014) found that a credit line is associated with cross-sectional variation in estimated speeds of adjustments of the target leverage because credit lines offer lower adjustment costs to under-levered firms. An, $\mathrm{Li}$, and $\mathrm{Yu}$ (2015) state that the exposure to a crash-risk diminishes the issue of capital structure speed of adjustment.

Considering Chang et al. (2015), product market competition leads companies with weak governance structures to increase the speed of adjustment of leverages. Halling et al. (2016) argue that the capital structure movements are counter-cyclical and determined by several variables. Li and Tang (2016) observed that the predominance of credit default swap-CDS referenced clients' revenues determine the speed of capital structure adjustments as CDS dilutes information faster than credit ratings.

Mu et al. (2017) found that the manager's moral hazard could represent a significant variable that influences debt issue and the optimal capital structure. Oliveira et al. (2017) identified that the capital structure of a supplier changes two years before a bankruptcy and converts to an optimal one in the process of reorganization, which is consistent to the bargaining power theory. Seo and Chung (2017) observed that companies have adjusted their capital structure through equity repurchase, in order to increase the stock prices instead of changing or issuing new debt. In addition, financial distress and incentives to the managers are important variables for doing so.

Sorokina et al. (2017) studied the reasons why the banks in the U.S. generally keep discretionary capital at higher levels, when compared to what regulations impose on them, suggesting that the banks' capital structure have been influenced by traditional non-financial capital structure determinants, competition, loan portfolio diversification, and liquidity creation.

Bakke and Gu (2017) found that diversification plays a significant role in cash holdings, investment, and the capital structure of industrial companies, which suggests a different variable for estimating companies' leverage. Devos et al. (2017) examined the relationship between debt covenants and the speed of capital structure adjustments, and observed that these have a negative relationship, particularly in capital covenants and in companies with higher debt-equity ratios. Tao et al. (2017) tested the hypothesis of acquiring companies that consider an optimal capital structure during mergers or acquisitions, and found evidence consistent to the dynamic trade-off theory.

Versmissen and Zietz (2017) found that there was a target for capital structure in the real estate industry and the 
speed for rebalancing such a structure toward the target is faster ( 0.6 a year), when compared to other industries, probably due to the dividend payout policy and the tangibility of assets in companies.

Cook and Tang (2010) observed that the speed of capital structure adjustment also depends on macroeconomic conditions, such as the term spread, default spread, gross domestic product - GDP growth rate, and dividend yield, although McMillan and Camara (2012) observed that multinational companies adjust their capital structure back to the target and lower than domestic companies, which could be related to return and leverage issues. However, Öztekin and Flannery (2012) confirmed that a country's financial development affects capital structure adjustments in approximately half of the cases. Fier, McCullough, and Carson (2013) observed that there is a statistical relation between the deviations from target leverage and the activity of the internal capital markets in the property-casualty insurance industry.

The macroeconomic conditions, such as the government leverage and output of financial sector from business credit and equity, have been found by Graham, Leary, and Roberts (2014) as the historical determinants of capital structures. An, $\mathrm{Li}$, and $\mathrm{Yu}(2015)$ have indicated a positive association between capital structure speed of adjustment and transparent information environment.

Considering banks, Lepetit, Saghi-Zedek, and Tarazi (2015) observed that banks with additional control rights, prefer drawing on earnings, in order to adjust their capital structure, mainly in countries with weaker shareholder protection or family-owned banks. Faulkender and Smith (2016) found empirical evidence that confirm the trade-off theory from the positive association between leverage and a country's tax rate. Schepens (2016) found that a reduction in tax shields of debts improve the issue of equity, leverage ratios, and credit risks of Belgian banks, which is consistent to the static trade-off theory. Shah et al. (2017) tested the hypothesis of the efficiency of law courts associated with managers' aversion to bankruptcy in a few countries, and found that the long-term leverage is negatively and significantly associated with the judiciary efficiency combined with the rights of creditors.

However, they found that the efficiency of the judiciary is positively associated with such leverage. Mai, Meng, and Ye (2017) found that regional development in China is a determinant for capital structure speed of adjustment, after analysing 783 listed companies' data from 2000 to 2014.

Sabiwalsky (2010) estimated capital targets throughout nonlinear structural equation and show the biggest companies have time varying optimal capital structures. Hovakimian and Li (2011) argued that traditional methods overestimate the importance of target debt ratios and such a bias could be minimized by estimating debt ratios from historical fixed firm effect regressions, such as separately using target and lagged debt ratios, and using the coefficient on target debt ratio to test the trade-off theory, in a manner similar to the one used by Flannery and Hankins (2013), related to data base possible biases.

Throughout the simulation process, Yang (2013) argued that including an increase in shareholders' strength improves the capital structure model specification. The challenges in model specification have been highlighted by Dang, Kim, and Shin (2015) in the robustness of results on capital structure adjustment studies. Liu et al. (2017) incorporated an incomplete information set in a learning model of the capital structure and found that the level of an agent's learning is a relevant factor in maintaining debt under the optimal capital structure. Xu and Yang (2017) developed a model of real option considering the illiquidity risk of secondary debt markets and found that the optimal capital structure increases with liquidity constraints.

\subsubsection{Market Microstructure and Corwin-Schultz Estimator}

Market microstructure is the process by which investors' latent demands are ultimately translated into transactions (Madhavan, 2000) or the study of trading mechanisms used for financial securities (Hasbrouck, 2007). Asymmetric information is one of the most prominent themes in market microstructure (Hasbrouck, 2007), and its relevance has a positive association with structural, technological, and regulatory improvements, and in areas of investments, financing, and capital structure (Madhavan, 2000).

The trading activity in sequential and strategic trader asymmetric information models reveal part of the agent's private information (Hasbrouck, 2007).

Roll's (1984) model uses the price of an asset to estimate the effective bid-ask spread, which contains the asymmetric information and is represented by the following equation: $=2 \sqrt{ }(-\operatorname{cov})$, where cov is the first-order serial covariance of price changes. French and Roll (1986) solved the minor sample bias of the former model to propose a new one, with the following equation: Spread= Var+ 2 cov. Several studies measure and offer improvements focusing on asymmetric information (Glosten \& Milgron, 1985; Glosten \& Harris, 1988; Hasbrouck, 1988; 1996; Hasbrouck, 1999) (Hasbrouck \& Seppi, 2001; Hasbrouck \& Saar, 2009; Roll \& 
Subrahmanyam, 2009; Hasbrouck \& Saar, 2013).

Another measure of asymmetric information is the probability of information-based trading-PIN, which was developed by Easley, Kiefer, and O'Hara (1997) and became a standard in financial literature. Such a measure is based on the level and first difference of intraday asset prices, quantity of buy and sell, as well as the algorithm of Lee and Ready (1991). Several studies have shown the relevance of asymmetric information on the main themes of finance (Easley, Hvidkjaer, \& O’Hara, 2002; Easley, O`Hara, \& Srinivas, 1998; Easley \& O’Hara, 2004; Chan, Menkveld, \& Yang, 2008).

In order to facilitate the computational process of asymmetric information, Corwin and Schultz (2012a) developed a bid-ask spread estimator from the daily high and low prices. Such a measure is based on the opening and closing, high and low prices of securities and has been presented in the following specification:

$$
\begin{gathered}
S=\frac{2\left(e^{\alpha}-1\right)}{1+e^{\alpha}} \\
\alpha=\frac{\sqrt{2 \beta}-\sqrt{\beta}}{3-2 \sqrt{2}}-\sqrt{\frac{\gamma}{3-2 \sqrt{2}}} \\
\beta=E\left\{\sum_{j=0}^{1}\left[\ln \left(\frac{H_{t+j}^{0}}{L_{t+j}^{0}}\right)\right]^{2}\right\} \\
\gamma=E\left\{\sum_{j=0}^{1}\left[\ln \left(\frac{H_{t, t+1}^{0}}{L_{t, t+1}^{0}}\right)\right]^{2}\right\}
\end{gathered}
$$

where the bid-ask spread estimator is based on (1), $\mathrm{S}$ is the spread, $\mathrm{e}$ is the natural logarithm (e basis) of $\mathrm{x}, \alpha$ is obtained from (2), $\beta$ from (3), and $\gamma$ from (4), and $\mathrm{H}$ and $\mathrm{L}$ are the observed high and low stock prices, respectively. The authors tested their measure in several countries (Corwin \& Schultz, 2012b) and made available the monthly/share stock market spreads for a wide range of shares in the U.S. They also derived their measure into a non-negative and overnight adjusted spread. The measures have been tested in abnormal returns, tangible economic gains and emerging markets, and for their consistency and financial reporting quality (Maskara \& Mullineaux, 2011; Karstanje, Sojli, Tham, \& Van Der Wel, 2013; Lin, 2014; Zhang, Yang, Su, \& Zhang, 2014; Cerqueira \& Pereira, 2014; Ripamonti, 2016).

This study is significantly different from the studies on the standard in capital structure adjustments (Leary \& Roberts, 2005; Byoun, 2008; Dang \& Garret, 2015) as it promotes the substitution of capital structure estimation for the direct measurement of capital structure. In addition, the target is represented by the cross-section and industry average debt to equity ratio for the entire period, and the deviations computed from such an average and the debt to equity ratio of the former quarter. A proposition such as this has the specific goal of enriching the essential characteristics of debt to equity ratio (Granger, 1981; Sabiwalsky, 2010), and allows to completely capture such features through cointegration techniques (Granger, 2010) and as a new alternative to the assumption of asset, debt, or stock issuance adjustment (Dang \& Garret, 2015).

The sample used in this study consists of 264 non-financial and non-regulated NYSE companies' data for 91 quarters. Johanser-Fisher panel cointegration was implemented on this sample data. The findings show that the capital structure changes are negatively and significantly associated with asymmetric information, while the deviation from the cross-section and the industry's capital structure targets are positively and significantly associated with asymmetric information. These two findings are consistent to the findings of other studies (DeAngelo, DeAngelo, \& Whited, 2011; Hovakimian \& Li, 2011; Dang, Kim, \& Shin, 2012; 2014).

This paper is divided method, that provides the characteristics of panel cointegration, and basic information on data and sample; results, with an analysis and discussion of the main findings; and concluding remarks, where the main theoretical and practical implications are presented.

\section{Method}

\subsection{Johansen-Fisher Panel Cointegration}

Cointegration is a long run relationship with a short run error correction vector, among non-stationary variables through their residuals' stationarity (Granger, 2010) and have been developed from unit root tests (Granger, 1981; Dickey \& Fuller, 1981) through a single equation approach (Engle \& Granger, 1987), multiple equation approach (Johansen, 1988; 1991), and Fisher-Johansen panel cointegration tests that allow for heterogeneity and multiple cointegrating vectors (Larsson, Lyhagen, \& Lothgren, 2001). 
Panel cointegration can be classified into residual-based and system panel cointegration tests (Örsal \& Arsova, 2017). The system tests allow the assessment of the number of ranks and the equation of a long run relationship between variables (Örsal \& Arsova, 2017), and have been applied in several studies.

Altunbas et al. (2016) applied the Westerlund panel cointegration techniques to ascertain that bank capital is positively associated with earning assets. Burret et al. (2016) also applied the Westerlund panel cointegration test to examine the financial sustainability of German states.

On the other hand, Li and Lin (2016) applied the IPS, Fischer-augmented Dickey-Fuller-ADF, Fischer-Phillips-Perron-PP, CADF unit root tests, and Pedroni panel cointegration using the fully modified ordinary least squares-FMOLS estimation method to test the long-term relationship among energy patents, prices, and GDP in China. Liu and Zhang (2016) examined the different banking market developments and insurance activities in several countries using Fisher panel cointegration with generalized method of moments-GMM estimation method, and Ahmad et al. (2017) applied the Pedroni and Johansen-Fisher panel cointegration tests to estimate the long run relationship among foreign direct investments, house consumption, exchange rate, gross capital, and GDP in the Brazil, Russia, India and China- BRIC countries.

Drakos et al. (2017) applied the dynamic panel cointegration model to assess the long run equation of savings and investments in 14 European Union countries, whereas Konopczak and Welfe (2017) applied three different kinds of panel cointegration models, including the Fisher-type Johansen test, in order to measure the long rung relationship among price, productivity, wages, and mark-up levels in four European countries.

Finally, Lim and Basnet (2017) applied the Fisher-ADF to assess the stationarity and Pedroni's panel cointegration tests to set the cointegration equation for GDP, consumption and remittances per capita, trade openness, and financial development of South-Asian countries, while Örsal and Arsova (2017) developed a new panel cointegration test based on individual likelihood ratios, and found reasonable properties, which were tested on a sample of exchange rates of developed and developing countries.

In this study, the Johansen-Fisher panel cointegration model (Larsson, Lyhagen, \& Lothgren, 2001) has been applied with an error correction model specification (5), where the panel's maximum likelihood and trace tests can be obtained as the average of each cross-sectional test, even in the presence of heterogeneity (Örsal \& Arsova, 2017), when compared to the likelihood ratio critical value asymptotic statistics from Larsson et al. (2001). In the vector error correction model-VECM specification without an intercept and a trend similar to (5), first part of the equation represents the variable's short run error correction mechanism, second one refers to the long run relationship vector, and last one is the disturbance term.

We gathered financial data from information services and the asymmetric information data from the Corwin-Schultz (2012b) supplementary materials. The data analysis has been made on Eviews9 (group statistics, Johansen cointegration test, test type - Fisher).

$$
\Delta Y_{i, t}=\Pi_{i} Y_{i, t-1}+\sum_{k=1}^{n} \Gamma_{i k} \Delta Y_{i, t-k}+v_{i, t}
$$

\subsection{Sample and Data}

Data of 264 non-financial and non-regulated NYSE listed companies from the second quarter of 1994 to the fourth quarter of 2016 have been analysed. The sample considered only the most liquid shares in the respective composite index. Although financial companies are found (Sorokina, Thornton Jr, \& Patel, 2017) to have the same non-financial determinants in their capital structure and identical capital structure targets, this study excluded these features as well as the regulated industries due to evident regulatory issues.

The averages debt to equity ratio for the whole period of each cross-section and industry, have been considered as the target capital structure, as an alternative to literature on estimating the same (Leary \& Roberts, 2005; Byoun, 2008; Dang \& Garret, 2015). This choice intended to achieve the fundamentals of leverage variable (Granger, 1981; Sabiwalsky, 2010), in order to avoid increasing noisy residuals and also to allow a better cointegration estimation (Granger, 2010) that is beyond the control of different adjustments due to debt, assets, or equity (Dang \& Garret, 2015). Another relevant issue is that standard capital structure estimation considers traditional determinants that are assumed to be control variables in this study.

The actual capital structure has been computed based on the former, in order to measure the level of integration of asymmetric information on the variation of capital structure, without considering any target.

The actual capital structure less the average of the whole period represents the deviation from the target capital structure and is intended to show how the adjustments behave for each company, particularly how the 
asymmetric information could cointegrate.

A similar theory has been applied to the industry capital structure target, as the average of each industry for the whole period has been used for the computation of deviation and to measure the impact of asymmetric information on adjustments.

Corwin and Schultz (2012b) computed and published the asymmetric information measure from non-negative and overnight adjusted bid-ask spread estimator (S_2) for the U.S. stock market from the first quarter of 1926 to the fourth quarter of 2014. This study used the source of "S_2" variable, in addition to different width as the Johansen-Fisher panel cointegration model allows for heterogeneity (Larsson, Lyhagen, \& Lothgren, 2001).

The variables used in the variation and deviation of debt to equity ratio, and that of asymmetric information variation have been analysed as model restricted variables (Johansen, 1988; 1991), while the traditional determinants of capital structure (Titman \& Wessels, 1988) representing the growth opportunities set, size and return are entered into the model as unrestricted variables that control companies' characteristics.

Table 1. Variables

\begin{tabular}{|c|c|c|}
\hline Variable & Description & Measure \\
\hline 1-VAR_DE & Variation of debt/equity ratio & $1-\left(D E_{i t} / D E_{i t-1}\right)$ \\
\hline DE-AV_ID_DE & Deviation from the target & $D E_{i t}-\frac{D E_{i}}{T}$ \\
\hline DE-AV_IND_DE & Deviation from the industry's target & $D E_{i t}-\frac{D E_{\text {ind }}}{T}$ \\
\hline S_2 & $\begin{array}{l}\text { Asymmetric information measure, CS bid ask spread estimator, non-negative and overnight } \\
\text { adjusted }\end{array}$ & Equation (1) \\
\hline MB & Market-to-book ratio & $P_{i t} / B O O K_{i t}$ \\
\hline SIZE & Size & Ln (revenues) \\
\hline RETURN & Variation of stock price & $P_{i t} / P_{i t-1}$ \\
\hline
\end{tabular}

Source: Author.

\subsection{Descriptive Statistics}

The variation in the mean capital structure was found to be 0.23 higher than the previous quarter, while such a movement clearly seems to be a forward company's and industry's target one, as the mean of deviation from both targets are close to zero, as presented in table 2. The asymmetric information measure was found to be approximately 0.02 per quarter, with a return of 0.13 per quarter -6.99 for market to book ratio and 15.56 for size on an average.

Table 2. Descriptive statistics

\begin{tabular}{|c|c|c|c|c|c|}
\hline Capital structure changes & 1-VAR_DE & S_2 & MB & SIZE & RETURN \\
\hline Mean & -0.235775 & 0.020539 & 6.993106 & 15.56039 & 0.132375 \\
\hline Median & 0.027360 & 0.017754 & 3.074481 & 15.51931 & 0.096802 \\
\hline Maximum & 1.000000 & 0.302415 & 9119.562 & 20.08545 & 14.66190 \\
\hline Minimum & -5.993 .088 & 0.001921 & 0.000000 & 10.84805 & 0.000000 \\
\hline Std. Dev. & 8.562572 & 0.011957 & 108.8491 & 1.498549 & 0.201203 \\
\hline Skewness & -6.236 .870 & 4.421949 & 72.41652 & 0.096376 & 44.07542 \\
\hline Kurtosis & 4077.528 & 56.07861 & 5791.788 & 2.629201 & 3136.291 \\
\hline Jarque-Bera & $6.01 \mathrm{E}+09$ & 1047346. & $1.21 \mathrm{E}+10$ & 63.17069 & $3.55 \mathrm{E}+09$ \\
\hline Probability & 0.000000 & 0.000000 & 0.000000 & 0.000000 & 0.000000 \\
\hline Sum & -2.046 .761 & 178.2979 & 60707.15 & 135079.7 & 1149.148 \\
\hline Sum Sq. Dev. & 636397.2 & 1.240986 & $1.03 \mathrm{E}+08$ & 19492.23 & 351.3911 \\
\hline Observations & 8681 & 8681 & 8681 & 8681 & 8681 \\
\hline Deviation from the target & DE-AV_ID_DE & S_2 & MB & SIZE & RETURN \\
\hline Mean & $1.02 \mathrm{E}-11$ & 0.021373 & 6.430516 & 15.37679 & 0.100586 \\
\hline Median & -0.018024 & 0.017153 & 2.914039 & 15.36020 & 0.068355 \\
\hline Maximum & 141.9747 & 1.003980 & 9119.562 & 20.08545 & 14.66190 \\
\hline Minimum & -8.379 .896 & 0.000786 & 0.000000 & 9.096029 & 0.000000 \\
\hline Std. Dev. & 1.556985 & 0.023746 & 82.83069 & 1.497936 & 0.152171 \\
\hline
\end{tabular}




\begin{tabular}{|c|c|c|c|c|c|}
\hline Skewness & 50.84690 & 17.75668 & 81.93020 & -0.027195 & 38.02522 \\
\hline Kurtosis & 4014.636 & 535.3066 & 8166.842 & 3.123412 & 3501.299 \\
\hline Jarque-Bera & $1.27 \mathrm{E}+10$ & $1.30 \mathrm{E}+08$ & $5.29 \mathrm{E}+10$ & 14.43354 & $1.23 \mathrm{E}+10$ \\
\hline Probability & 0.000000 & 0.000000 & 0.000000 & 0.000734 & 0.000000 \\
\hline Sum & $1.92 \mathrm{E}-07$ & 234.9703 & 122379.2 & 292851.0 & 2416.469 \\
\hline Sum Sq. Dev. & 45713.18 & 6.198734 & $1.31 \mathrm{E}+08$ & 42731.16 & 556.2736 \\
\hline Observations & 18858 & 10994 & 19031 & 19045 & 24024 \\
\hline Deviation from the industry's target & DE-AV_IND_DE & S_2 & MB & SIZE & RETURN \\
\hline Mean & $1.39 \mathrm{E}-11$ & 0.021373 & 6.430516 & 15.37679 & 0.100586 \\
\hline Median & -0.067512 & 0.017153 & 2.914039 & 15.36020 & 0.068355 \\
\hline Maximum & 147.0882 & 1.003980 & 9119.562 & 20.08545 & 14.66190 \\
\hline Minimum & -3.266 .409 & 0.000786 & 0.000000 & 9.096029 & 0.000000 \\
\hline Std. Dev. & 1.656336 & 0.023746 & 82.83069 & 1.497936 & 0.152171 \\
\hline Skewness & 49.66412 & 17.75668 & 81.93020 & -0.027195 & 38.02522 \\
\hline Kurtosis & 3691.112 & 535.3066 & 8166.842 & 3.123412 & 3501.299 \\
\hline Jarque-Bera & $1.07 \mathrm{E}+10$ & $1.30 \mathrm{E}+08$ & $5.29 \mathrm{E}+10$ & 14.43354 & $1.23 \mathrm{E}+10$ \\
\hline Probability & 0.000000 & 0.000000 & 0.000000 & 0.000734 & 0.000000 \\
\hline Sum & $2.61 \mathrm{E}-07$ & 234.9703 & 122379.2 & 292851.0 & 2416.469 \\
\hline Sum Sq. Dev. & 51733.24 & 6.198734 & $1.31 \mathrm{E}+08$ & 42731.16 & 556.2736 \\
\hline Observations & 18858 & 10994 & 19031 & 19045 & 24024 \\
\hline
\end{tabular}

Note. Table 2 presents the descriptive statistics of variables segregated into three different samples (capital structure changes, deviation from the target, and deviation from industry's target). Capital structure changes refer to the sample with the variable [1-(debt/equity ratio of $\mathrm{t} /$ debt/equity ratio of t-1)]; deviation from the target is the sample with the variable (debt/equity ratio less average debt/equity ratio); and deviation from the industry's target is with the variable (debt/equity ratio less industry average debt/equity ratio). Individual sample refers to statistics for all non-missing observations for each series and common sample is any of the series in the group.

Source: Author.

An increase in debt to equity ratio presented negative correlation to asymmetric information and returns, in addition to showing a positive correlation with market-to-book ratio and size. It can be assumed that asymmetric information has a relevant role in capital structure movements. A higher asymmetric information results in a higher adjustment toward a target, which is consistent to the theoretical framework. However, the deviation from the targets presented a positive correlation to asymmetric information. This confirms that the magnitude of asymmetric information generates deviations and subsequent adjustments on the capital structure of companies, including those related to their industries.

Table 3. Correlation matrix

\begin{tabular}{cccccc}
\hline Changes & 1-VAR_DE & S_2 & MB & SIZE & RETURN \\
\hline 1-VAR_DE & 1.000000 & -0.003873 & 0.000883 & 0.011009 & -0.001573 \\
S_2 & -0.003873 & 1.000000 & -0.008882 & -0.144852 & 0.218601 \\
MB & 0.000883 & -0.008882 & 1.000000 & -0.010372 & -0.007825 \\
SIZE & 0.011009 & -0.144852 & -0.010372 & 1.000000 & -0.094716 \\
RETURN & -0.001573 & 0.218601 & -0.007825 & -0.094716 & 1.000000 \\
\hline Target & DE-AV_ID_DE & S_2 & MB & SIZE & RETURN \\
\hline DE-AV_ID_DE & 1.000000 & 0.143493 & -0.005553 & -0.024306 & 0.033362 \\
S_2 & 0.143493 & 1.000000 & -0.007668 & -0.104191 & 0.231447 \\
MB & -0.005553 & -0.007668 & 1.000000 & -0.004441 & -0.006832 \\
SIZE & -0.024306 & -0.104191 & -0.004441 & 1.000000 & -0.068296 \\
RETURN & 0.033362 & 0.231447 & -0.006832 & -0.068296 & 1.000000 \\
Industry & DE-AV_ID_DE & S_2 & MB & SIZE & RETURN \\
DE-AV_IND_DE & 1.000000 & 0.204609 & -0.005397 & 0.052270 & 0.042732 \\
S_2 & 0.204609 & 1.000000 & -0.007668 & -0.104191 & 0.231447 \\
MB & -0.005397 & -0.007668 & 1.000000 & -0.004441 & -0.006832 \\
SIZE & 0.052270 & -0.104191 & -0.004441 & 1.000000 & -0.068296 \\
RETURN & 0.042732 & 0.231447 & -0.006832 & -0.068296 & 1.000000 \\
\hline
\end{tabular}

Note. Table 3 presents the correlation matrix of variables segregated into the three different samples described in table 2.

Source: Author. 


\section{Results}

One of the main assumptions of a cointegration system (Granger, 1981; Engle \& Granger, 1987) is that the restricted variables are not stationary (Johansen, 1988; 1991). Table 4 shows that the ADF-Fisher test (Larsson, Lyhagen, \& Lothgren, 2001) rejects the null of no-cointegration for all the examined variables. This is confirmed by the MAX and TRACE tests (Johansen, 1991) in their panel cointegration version (Larsson, Lyhagen, \& Lothgren, 2001), the results of which show the existence of several ranks of cointegration for the unrestricted model, suggesting that the relationship between the variables can be expressed in four cointegration equations, as shown in table 4.

However, when the model is specified as a restricted one, where the capital structure changes or deviations with regard to the targets, asymmetric information are relevant variables, and when market-to-book $\mathrm{M} / \mathrm{B}$, size, and return are unrestricted and control variables, the Fisher-Rank test shows the existence of only one cointegration equation to explain such a relationship, as presented in Table 4.

In addition, the results of unit root tests for capital structure changes and deviations from targets mean that the behaviour of the debt to equity ratio is at all times target forward, consistent to the trade-off theory (Modigliani \& Miller, 1963); and the industry target is also expected to be attained, which could be due to competition issues (Chang, Chen, Chou, \& Huang, 2015) or different sort of target estimation (Sabiwalsky, 2010).

Combining such evidence with the optimal lag choice information criterion and the restricted model lags chosen from Table 4, it is possible to observe that the capital structure adjustments could occur between the second and fourth quarters.

Model 1 in Table 4 presents the negative and significant association between capital structure changes and asymmetric information. Specifically, it refers to the increase of debt-to-equity ratio (in this case represented by more negative figures), which is determined by the increasing asymmetric information in the same period of time. This asymmetric information loses significance from the second to fourth quarter, although the variable debt-to-equity ratio keeps the significance for determining the whole system, in a clear stationary process.

The inverted relationship sense of "S_2" and the capital structure changes related to the actual quarter confirm "target forwarding" in the subsequent quarters. The capital structure changes or "S_2" invert the signal of the first quarter, reinforcing the movement of capital structure adjustment toward a target.

Similar results were found by Andres et al. (2014) for a NASDAQ sample, while applying a proxy for asymmetric information and examining the data for pooled, fixed, and random effects traditional panel data methods, for a different period when compared to this study.

The influence of asymmetric information on capital structure adjustments is also consistent to the diminishing speed of adjustment in the disclosure environment as observed by $\mathrm{An}, \mathrm{Li}$, and $\mathrm{Yu}$ (2015) and the weak corporate governance structure (Grahan, Leary, \& Roberts, 2014; Lepetit, Saghi-Zedek, \& Tarazi, 2015).

The findings of the capital structure changes are confirmed by models 2 and 3 in table 4 . Considering the cross-section and industry cases, asymmetric information has a positive and significant role in the deviation from the target. However, the relationships and their significance follow the same path as the former one, with inversion in sense and loss of significance for asymmetric information.

This study did not undertake a different estimation for the several financial crises. However, considering the findings of Cook \& Tang (2010), it can be observed that the average deviations show similar behaviour in all situations, which could be explained by the easy access to the financial markets (Cook \& Tang, 2010), liquidity of shares and stock market development (Demirgüc-Kunt \& Maksimovic, 1996; Öztekin \& Flannery, 2012), and the internal financial market (Fier, McCullough, \& Carson, 2013). The influence of financial crises is also consistent to the dynamics of capital structure (DeAngelo, DeAngelo, \& Whited, 2011; Hovakimian \& Li, 2011) and the different characteristics at a company level (Dang, Kim, \& Shin, 2012; Dang, Kim, \& Shin, 2014). 
Table 4. Unit root tests, rank test, and VECM estimates

\begin{tabular}{|c|c|c|c|c|c|c|c|}
\hline \multicolumn{8}{|c|}{ UNIT ROOT TESTS } \\
\hline \multirow[t]{2}{*}{ Method } & \multicolumn{7}{|c|}{ Variables } \\
\hline & 1-var_de & de-av_id_de & de-av_ind_de & S_2 & MB & SIZE & RETURN \\
\hline LLC & 0.0000 & 0.0036 & 0.0036 & 0.0000 & 0.0000 & 1.0000 & 0.0000 \\
\hline Breitung & 0.0000 & 1.0000 & 1.0000 & 0.0000 & 0.4858 & 0.6232 & 0.0000 \\
\hline IPS & 0.0000 & 0.0000 & 0.0000 & 0.0000 & 0.0000 & 0.0000 & 0.0000 \\
\hline ADF-Fisher & 0.0000 & 0.0000 & 0.0000 & 0.0000 & 0.0000 & 0.0000 & 0.0000 \\
\hline PP-Fisher & 0.0000 & 0.0000 & 0.0000 & 0.0000 & 0.0000 & 0.0000 & 0.0000 \\
\hline \multicolumn{8}{|c|}{ FISHER RANK TEST } \\
\hline Unrestricted & 4 & 4 & 4 & & & & \\
\hline \multicolumn{8}{|l|}{ Restricted } \\
\hline \multicolumn{8}{|c|}{ VECM ESTIMATES } \\
\hline & & \multicolumn{2}{|c|}{ Model 1} & \multicolumn{2}{|c|}{ Model 2} & \multicolumn{2}{|c|}{ Model 3} \\
\hline & & coef. & t-stat & coef. & t-stat & coef. & t-stat \\
\hline \multicolumn{8}{|c|}{ Cointegration equation } \\
\hline 1-VAR_DE & & 1.000000 & & & & & \\
\hline DE-AV_ID_DE & & & & 1.000000 & & & \\
\hline DE-AV_IND_DE & & & & & & 1.000000 & \\
\hline S_2 & & -3501.4790 & -23.3519 & 4624.9760 & 29.6729 & -1060.9290 & -30.1322 \\
\hline Constant & & 72.362730 & & -94.773000 & & 21.727970 & \\
\hline \multicolumn{8}{|l|}{ Error correction } \\
\hline 1-VAR_DE (-1) & & -0.970772 & -82.947700 & & & & \\
\hline 1-VAR_DE (-2) & & -0.948017 & -59.206400 & & & & \\
\hline 1-VAR_DE (-3) & & -0.931384 & -48.360600 & & & & \\
\hline 1-VAR_DE (-4) & & -0.453148 & -11.365700 & & & & \\
\hline DE-AV_ID_DE (-1) & & & & 0.288184 & 24.782900 & & \\
\hline DE-AV_ID_DE (-2) & & & & -0.247474 & -19.446900 & & \\
\hline DE-AV_IND_DE (-1) & & & & & & 0.288559 & 24.806700 \\
\hline DE-AV_IND_DE (-2) & & & & & & -0.247277 & -19.437000 \\
\hline$S \_2(-1)$ & & -5.855850 & -0.388360 & 1.781973 & 2.765120 & 1.656769 & 2.563310 \\
\hline S_2 (-2) & & 4.935737 & 0.333660 & 0.607971 & 0.973300 & 0.514763 & 0.823070 \\
\hline$S \_2(-3)$ & & -7.138713 & -0.062563 & & & & \\
\hline S_2 (-4) & & 9.885883 & 0.718910 & & & & \\
\hline Constant & & -0.629853 & -0.560350 & -0.053984 & -1.150540 & -0.565270 & -1.204120 \\
\hline $\mathrm{MB}$ & & 0.000044 & 0.049160 & -0.000007 & -0.147750 & -0.000007 & -0.146300 \\
\hline SIZE & & 0.033915 & 0.475440 & 0.004531 & 1.501180 & 0.004715 & 1.561420 \\
\hline RETURN & & -0.150082 & -0.291960 & -0.095939 & -3.864030 & -0.098357 & -3.963400 \\
\hline R-squared & & 0.487677 & & 0.099638 & & 0.099717 & \\
\hline Adj. R-squared & & 0.486891 & & 0.098843 & & 0.098922 & \\
\hline Sum sq. resids & & 647387.6 & & 1842.948 & & 1842.786 & \\
\hline S.E. equation & & 9.099853 & & 0.450992 & & 0.450972 & \\
\hline F-statistic & & 620.1599 & & 125.3409 & & 125.4518 & \\
\hline Log likelihood & & -28398.07 & & -5642.771 & & -5642.371 & \\
\hline Akaike AIC & & 7.256052 & & 1.246256 & & 1.246168 & \\
\hline Schwarz SC & & 7.267616 & & 1.253314 & & 1.253226 & \\
\hline Mean dependent & & 0.005393 & & 0.003695 & & 0.003695 & \\
\hline S.D. dependent & & 12.70368 & & 0.475082 & & 0.475082 & \\
\hline
\end{tabular}

Note. Table 4 presents the unit root tests, maximum likelihood and trace statistics, and cointegration equations for the restricted models containing capital structure changes, deviation from the cross-section target, and deviation from the industry target. The unit root tests have the null of no-cointegration of variable time series and present the p-values of the tests for each variable. The Fisher rank test presents only the number of cointegration equations where the maximum likelihood and trace statistics converge, and where the number of cointegration equations jointly explain the relationship. "Unrestricted" refers to the models with five variables, and "restricted" is related to models with two restricted variables and three unrestricted ones. The relationship between restricted variables has been chosen from the Akaike and Schwarz Bayesian information criterion, with four lags for capital structure changes and two lags for deviation from the targets. VECM estimates present the long run relationship coefficients and its correction in the short run, all with coefficient followed by their t-statistics for checking the significance of the results.

Source: Author. 


\section{Discussion}

The impact of asymmetric information is significant, both in the capital structure changes and in the deviations of a company's or industry's capital structure targets. However, such a long run relationship is strongly influenced by its own capital structure movement.

Further, the dynamic trade-off theory is improved from two aspects. First, beyond the seminal works of tax shield and bankruptcy risk, the deviations and subsequent movement toward a target are influenced by asymmetric information that could be captured by a measure that is easy to compute and available. Second, the power of capital structure stationarity has to be considered in the model specifications. The influence of deviations from the target lasted for approximately four quarters, while the influence of another variable in the restricted model lasted for a single quarter. The dynamics of the capital structure warranted model specifications related to other variables in asymmetric information and traditional capital structure determinants. Such a finding relates to the pecking-order theory, where asymmetric information is among its foundations.

In financial market activities, particularly in portfolio selection, this study's findings suggest the monitoring of the asymmetric information measure. Despite being significant in only one quarter, the capital structure movements can be predicted, and consequently, the companies' strategic issues can be observed in advance, in addition to the managers' competing interests.

Panel cointegration appears to be a reliable model for assessing firm level capital structure decisions as well. It aligns the strength of panel data, generally applied in financial studies, to the powerful dynamics of time series. Such models could be useful in analysing several aspects of a capital structure.

The initial supposition of this study that asymmetric information has a relevant role in capital structure adjustments, seems to be confirmed. Furthermore, it was possible to find other prospects in the dynamics of funding decisions.

Certainly, the findings could be improved from different aspects, such as the inclusion of macroeconomic conditions, and developing markets and measures of capital structure adjustment on the models.

Therefore, this research has implications and innovations in some aspects, such as the estimates and analysis of capital structure adjustments, validation of the easy way of measuring asymmetric information and its consequences on the theoretical framework and an additional tool for the investors to forecast companies' strategic decisions.

\section{References}

Ahmad, F., Nasir, M., \& Ahmad, M. (2017). Foreign direct investment, aggregate demand conditions and exchange rate nexus: A panel data analysis of BRICS economies. Research in International Business and Finance. https://doi.org/10.1016/j.ribaf.2017.04.041

Akerlof, G. (1970). The market for "lemons": Quality uncertainty and the market mechanism. The Quarterly Journal of Economics, 84(3), 488-500. https://doi.org/10.2307/1879431

Altunbas, Y., Di Tommaso, C., \& Thornton, J. (2016). Do better-capitalizes banks lend less? Evidence from European banks. Finance Research Letters, 17, 246-250. https://doi.org/10.1016/j.frl.2016.03.022

An, Z., Li, D., \& Yu, J. (2015). Firm crash risk, information environment, and speed of leverage adjustment. Journal of Corporate Finance, 31, 132-151. https://doi.org/10.1016/j.jcorpfin.2015.01.015

Andres, C., Cumming, D., Karabiber, T., \& Schweizer, D. (2014). Do markets anticipate capital structure decisions? Feedback effects in equity liquidity. Journal of Corporate Finance, 27, 133-156. https://doi.org/10.1016/j.jcorpfin.2014.02.006

Bakke, T., \& Gu, T. (2017). Diversification and cash dynamics. Journal of Financial Economics, 123, 580-601. https://doi.org/10.1016/j.jfineco.2016.12.008

Burret, H., Feld, L., \& Köhler, E. (2016). (Un-)Sustainability of public finances in German Laender: A panel time series approach. Economic Modelling, 53, 254-265. DOI: https://doi.org/10.1016/j.econmod.2015.12.001

Byoun, S. (2008). How and when do firms adjust their capital structures toward targets? The Journal of Finance, LXIII(6), 3069-3096. https://doi.org/10.1111/j.1540-6261.2008.01421.x

Cerqueira, A., \& Pereira, C. (2014). Financial reporting quality and information asymmetry in Europe. British Accounting Review, 32-51. Retrieved from https://bafa.group.shef.ac.uk/submission_system/view_submissions/index.php?download_paper=41 
Chan, K., Menkveld, A., \& Yang, Z. (2008). Information asymmetry and asset prices: Evidence from the China foreign share discount. The Journal of Finance, 159-196. https://doi.org/10.1111/j.1540-6261.2008.01313.x

Chang, Y., Chen, Y., Chou, R. K., \& Huang, T. (2015). Corporate governance, product market competition and dynamic capital structure. Internation Review of Economics and Finance. https://doi.org/10.1016/j.iref.2014.12.013

Cook, D., \& Tang, T. (2010). Macroeconomic conditions and capital structure adjustment speed. Journal of Corporate Finance, 16, 73-87. https://doi.org/10.1016/j.jcorpfin.2009.02.003

Corwin, S., \& Schultz, P. (2012a). A simple way to estimate bid and ask spreads from daily high and low prices. The Journal of Finance, 719-759. https://doi.org/10.1111/j.1540-6261.2012.01729.x

Corwin, S., \& Schultz, P. (2012b). Internet appendix for "A simple way to estimate bid-ask spreads from daily high and low prices". The Journal of Finance, 719-759. https://doi.org/10.1111/j.1540-6261.2012.01729.x

Dang, V. A., Kim, M., \& Shin, Y. (2012). Asymmetric capital structure adjustments: New evidence from dynamic panel threshold models. Journal of Empirical Finance, 19, 465-482. https://doi.org/10.1016/j.jempfin.2012.04.004

Dang, V., \& Garret, I. (2015). On capital structure adjustments. Finance Research Letters, 14, 56-63. DOI: https://doi.org/10.1016/j.frl.2015.05.016

Dang, V., Kim, M., \& Shin, Y. (2014). Asymmetric adjustment toward optimal capital structure: Evidence from a crisis. International Review of Financial Analysis, 33, 226-242. https://doi.org/10.1016/j.irfa.2014.02.013

Dang, V., Kim, M., \& Shin, Y. (2015). In search of robust methods for dynamic panel data models in empirical corporate finance. Journal of Banking \& Finance, 53, 84-98. https://doi.org/10.1016/j.jbankfin.2014.12.009

DeAngelo, H., DeAngelo, L., \& Whited, T. (2011). Capital structure dynamics and transitory debt. Journal of Financial Economics, 99, 235-261. https://doi.org/10.1016/j.jfineco.2010.09.005

Demirgüc-Kunt, A., \& Maksimovic, V. (1996). Stock market development and financing choices of firms. The World Bank Economic Review, 10(2), 341-369. https://doi.org/10.1093/wber/10.2.341

Demirgüc-Kunt, A., Feyen, E., \& Levine, R. (2013). The evolving importance of banks and securities markets. The World Bank Economic Review, 27(3), 476-490. https://doi.org/10.1093/wber/lhs022

Devos, E., Rahman, S., \& Tsang, D. (2017). Debt covenants and the speed of capital structure adjustment. Journal of Corporate Finance, 45, 1-18. https://doi.org/10.1016/j.jcorpfin.2017.04.008

Dickey, D., \& Fuller, W. (1981). Likelihood ratio statistics for autoregressive time series with a unit root. Econometrica, 1057-1072. https://doi.org/10.2307/1912517

Drakos, A., Kouretas, G., Stavroyiannis, S., \& Zarangas, L. (2017). Is the Feldstein-Horioka puzzle still with us? National saving-investment dynamics and international capital mobility: A panel data analysis across EU member countries. Journal of International Financial Markets, Institutions \& Money, 47, 76-88. DOI: https://doi.org/10.1016/j.intfin.2016.11.006

Easley, D., \& O'Hara, M. (1991). Order form and information in securities markets. The Journal of Finance, 46(3), 905-927. https://doi.org/10.1111/j.1540-6261.1991.tb03771.x

Easley, D., \& O’Hara, M. (2004). Information and cost of capital. The Journal of Finance, 59(4), 1553-1583. https://doi.org/10.1111/j.1540-6261.2004.00672.x

Easley, D., Hvidkjaer, S., \& O`Hara, M. (2002). Is information risk a determinant of asset returns? The Journal of Finance, 57(5), 2185-2221. https://doi.org/10.1111/1540-6261.00493

Easley, D., Kiefer, N., \& O'Hara, M. (1997). One day in the life of a very common stock. The Review of Financial Studies, 10(3), 805-835. https://doi.org/10.1093/rfs/10.3.805

Easley, D., O`Hara, M., \& Srinivas, P. (1998). Option volume and stock prices: Evidences on where informed traders trade. The Journal of Finance, 53(2), 431-465. https://doi.org/10.1111/0022-1082.194060

Engle, R., \& Granger, C. (1987). Co-integration and error correction: representation, estimation and testing. Econometric, 55(2), 251-276. https://doi.org/10.2307/1913236

Faulkender, M., \& Smith, J. (2016). Taxes and leverage at multinational corporations. Journal of Financial Economics, 122, 1-20. https://doi.org/10.1016/j.jfineco.2016.05.011

Faulkender, M., Flannery, M., Hankins, K., \& Smith, J. (2012). Cash flows and leverage adjustments. Journal of 
Financial Economics, 103, 632-646. https://doi.org/10.1016/j.jfineco.2011.10.013

Fier, S., McCullough, K., \& Carson, J. (2013). Internal capital markets and the partial adjustment of leverage. Journal of Banking and Finance, 37, 1029-1039. https://doi.org/10.1016/j.jbankfin.2012.11.003

Flannery, M., \& Hankins, K. (2013). Estimating dynamic panel models in corporate finance. Journal of Corporate Finance, 19, 1-19. https://doi.org/10.1016/j.jcorpfin.2012.09.004

French, K., \& Roll, R. (1986). Stock return variances The arrival of information and the reaction of traders. The Journal of Financial Economics, 17, 5-26. Retrieved from http://www.sciencedirect.com/science/article/B6VBX-458WN9H-H/2/44fd7882c954da27b9afcbdbbca674c 6.

Glosten, L., \& Harris, L. (1988). Estimating the components of bid/ask spread. Journal of Financial Economics, 123-142. Retrieved from http://ac.els-cdn.com.ez67.periodicos.capes.gov.br/0304405X88900347/1-s2.0-0304405X88900347-main.p df?_tid=86c30bfc-beae-11e4-bdca-00000aacb35f\&acdnat=1425061932_a8ef915f92b956be1f938d4477253 $1 \mathrm{a} 8$.

Glosten, L., \& Milgron, P. (1985). Bid, ask and transaction prices in a specialist market with heterogeneously informed traders. Journal of Financial Economics, (14), 71-100. Retrieved from http://ac.els-cdn.com.ez67.periodicos.capes.gov.br/0304405X85900443/1-s2.0-0304405X85900443-main.p df?_tid=4ee73cba-beab-11e4-8faa-00000aacb362\&acdnat=1425060550_c2e2f2a301a5ece3010dd7cf5cf7d1 ca.

Grahan, J., Leary, M., \& Roberts, M. (2014). A century of capital structure: The leveraging of corporate America. Journal of Financial Economics. https://doi.org/10.1016/j.jfineco.2014.08.005

Granger, C. (1981). Some properties of time series data and their use in econometric model specification. Journal of Econometrics, 16, 121-130. Retrieved from http://ac.els-cdn.com.ez67.periodicos.capes.gov.br/0304407681900798/1-s2.0-0304407681900798-main.pd f?_tid=ff5d3380-beae-11e4-8762-00000aacb35e\&acdnat=1425062134_77918a3735b14dec4b4deca755d87 91f.

Granger, C. (2010). Some thoughts on the development of cointegration. Journal of Econometrics, 158, 3-6. https://doi.org/10.1016/j.jeconom.2010.03.002

Halling, M., Yu, J., \& Zechner, J. (2016). Leverage dynamics over the business cycle. Journal of Financial Economics, 122, 21-41. https://doi.org/10.1016/j.jfineco.2016.07.001

Hasbrouck, J. (1988). Trades, quotes, inventories, and information. Journal of Financial Economics, 229-252. https://doi.org/10.1016/0304-405X(88)90070-0

Hasbrouck, J. (1991). Measuring the information content of stock trades. The Journal of Finance, 46(1), 179-207. https://doi.org/10.1111/j.1540-6261.1991.tb03749.x

Hasbrouck, J. (1996). Order characteristics and stock price evolution: An application to program trading. Journal of Financial Economics, 4, 129-149. https://doi.org/10.1016/0304-405X(95)00858-C

Hasbrouck, J. (1999). Security bid/ask dynamics with discreteness and clustering: Simple strategies for modeling and estimation. Journal of Financial Markets, 2, 1-28. Retrieved from http://ac.els-cdn.com.ez67.periodicos.capes.gov.br/S1386418198000081/1-s2.0-S1386418198000081-main. pdf?_tid=08ad4274-beb2-11e4-9c1e-00000aab0f26\&acdnat=1425063438_93f0d42ad7f6940a3b2d72ceda3 $81 \mathrm{~cd} 2$.

Hasbrouck, J. (2007). Empirical market microstructure: the institutions, economics, and econometrics of securities trading. New York: Oxford University Press.

Hasbrouck, J., \& Saar, G. (2009). Technology and liquidity provision: The blurring of traditional definitions. Journal of Financial Markets, 143-172. https://doi.org/10.1016/j.finmar.2008.06.002

Hasbrouck, J., \& Saar, G. (2013). Low-latency trading. Journal of Financial Markets, 646-679. https://doi.org/10.1016/j.finmar.2013.05.003

Hasbrouck, J., \& Seppi, D. (2001). Common factors in prices, order flows, and liquidity. Journal of Financial Economics, 
5ae507d.

Hovakimian, A., \& Li, G. (2011). In search of conclusive evidence: How to test for adjustment to target capital structure. Journal of Corporate Finance, 17, 33-44. https://doi.org/10.1016/j.jcorpfin.2010.07.004

Jensen, M., \& Meckling, W. (1976). Theory of firm: managerial behavior, agency costs and ownership structure. Journal of Financial Economics. 3(4), 305-360. https://doi.org/10.1016/0304-405X(76)90026-X

Johansen, S. (1988). Statistical analysis of cointegration vectors. Journal of Economics Dynamics and Control. 12(2-3), 231-254. https://doi.org/10.1016/0165-1889(88)90041-3

Johansen, S. (1991). Estimation and hypothesis testing of cointegration. Econometrica, 1551-1580. https://doi.org/10.2307/2938278

Karstanje, D., Sojli, E., Tham, W., \& Van Der Wel, M. (2013). Economic valuation of liquidity timing. Journal of Banking \& Finance, 37, 5073-5087. https://doi.org/10.1016/j.jbankfin.2013.09.010

Konopczak, K., \& Welfe, A. (2017). Convergence-driven inflation and the channels of its absorption. Journal of Policy Modelling. https://doi.org/10.1016/j.jpolmod.2017.02.001

Larsson, R., Lyhagen, J., \& Lothgren, M. (2001). Likelihood based cointegration tests in heterogeneous panels. Econometrics Journal, 4(2), 109-142. https://doi.org/10.1111/1368-423X.00059

Leary, M., \& Roberts, M. (2005). Do firms rebalance their capital structures? The Journal of Finance, LX(6), 2575-2619. https://doi.org/10.1111/j.1540-6261.2005.00811.x

Lee, C., \& Ready, M. (1991). Inferring trade direction from intraday data. The Journal of Finance, 46(2), 733-746. https://doi.org/10.2307/2328845

Lepetit, L., Saghi-Zedek, N., \& Tarazi, A. (2015). Excess control rights, bank capital structure adjustments, and lending. Journal of Financial Economics, 115, 574-591. https://doi.org/10.1016/j.jfineco.2014.10.004

Li, J., \& Tang, D. (2016). The leverage externalities of credit default swaps. Journal of Financial Economics, 120, 491-513. https://doi.org/10.1016/j.jfineco.2016.02.005

Li, K., \& Lin, B. (2016). Impact of energy technology patents in China: Evidence from a panel cointegration and error correction model. Energy Policy, 89, 214-223. https://doi.org/10.1016/j.enpol.2015.11.034

Lim, S., \& Basnet, H. (2017). International migration, workers' remittances and permanent income hypothesis. World Development. https://doi.org/10.1016/j.worlddev.2017.03.028

Lin, C. (2014). Estimation accuracy of high-low spread estimator. Finance Research Letters, 11, 54-62. https://doi.org/10.1016/j.frl.2013.05.004

Liu, B., Liu, Y., Pen, J., \& Yang, J. (2017). Optimal capital structure and credit spread under incomplete information. International Review of Economics and Finance, 49, 596-611. https://doi.org/10.1016/j.iref.2017.03.020

Liu, G., \& Zhang, C. (2016). The dynamic linkage between insurance activities and banking credit: Some new evidence from global countries. International Review of Economics and Finance, 44, 40-53. https://doi.org/10.1016/j.iref.2016.03.002

Lockhart, G. (2014). Credit lines and leverage adjustments. Journal of Corporate Finance, 25, 274-288. https://doi.org/10.1016/j.jcorpfin.2013.12.011

Madhavan, A. (2000). Market microstructure: A survey. Journal of Financial Markets, 3, 205-258. Retrieved from

http://ac.els-cdn.com.ez67.periodicos.capes.gov.br/S1386418100000070/1-s2.0-S1386418100000070-main. pdf?_tid=fd15696c-beb3-11e4-8b40-00000aacb362\&acdnat=1425064278_7be6f98e7ee4972a9363bc1f02d 19f4a.

Mai, Y., Meng, L., \& Ye, Z. (2017 ). Regional variation in the capital structure adjustment speed of listed firms: Evidence from China. Economic Modelling 64, 288-294. https://doi.org/10.1016/j.econmod.2017.03.028

Maskara, P., \& Mullineaux, D. (2011). Information asymmetry and self-selection bias in bank loan announcement studies. Journal of Financial Economics, 101, 684-694. https://doi.org/10.1016/j.jfineco.2011.03.019

McMillan, D., \& Camara, O. (2012). Dynamic capital structure adjustment: US MNCs \& DCs. Journal of Multinational Financial Management, 22, 278-301. https://doi.org/10.1016/j.mulfin.2012.10.001 
Modigliani, F., \& Miller, M. (1958). The cost of capital, corporation finance and the theory of investment. The American Economic Review, 261-297. Retrieved from https://www.jstor.org/stable/1809766.

Modigliani, F., \& Miller, M. (1963). Corporate income taxes and cost of capital: a correction. American Economic Review, 433-443. Retrieved from https://www.jstor.org/stable/1809167.

Mu, C., Wang, A., \& Yang, J. (2017). Optimal capital structure with moral hazard. International Review of Economics and Finance, 48, 326-338. https://doi.org/10.1016/j.iref.2016.12.006

Myers, S., \& Majluf, N. (1984). Corporate financing and investment decisions when firms have information that investors do not have. Journal of Financial Economics, 13(2), 187-221. https://doi.org/10.3386/w1396

Oliveira, M., Kadapakkam, P., \& Beyhaghi, M. (2017). Effects of customer financial distress on supplier capital structure. Journal of Corporate Finance, 42, 131-149. DOI: https://doi.org/10.1016/j.jcorpfin.2016.11.009

Örsal, D., \& Arsova, A. (2017). Meta-analytic cointegration rank tests for dependent panels. Econometrics and Statistics, 2, 61-72. https://doi.org/10.1016/j.ecosta.2016.10.001

Öztekin, O., \& Flannery, M. (2012). Institutional determinants of capital structure adjustment speeds. Journal of Financial Economics, 103, 88-112. https://doi.org/10.1016/j.jfineco.2011.08.014

Ripamonti, A. (2016). Corwin-Schultz bid-ask spread estimator in the brazilian stock Market. BAR, 13(1), 76-97. https://doi.org/10.1590/1807-7692bar2016150036

Roll, R. (1984). A simple implicit measure of the effective bid-ask spread in an efficient market. The Journal of Finance, 1127-1139. https://doi.org/10.1111/j.1540-6261.1984.tb03897.x

Roll, R., \& Subrahmanyam, A. (2009). Liquidity skewness. Journal of Banking and Finance, 143-172. https://doi.org/10.1016/j.jbankfin.2010.04.012

Sabiwalsky, R. (2010). Nonlinear modelling of target leverage with latent determinant variables - new evidence on the trade-off theory. Review of Financial Economics, 19(4), 137-150. https://doi.org/10.1016/j.rfe.2010.06.001

Schepens, G. (2016). Taxes and bank capital structure. Journal of Financial Economics, 120, 585-600. https://doi.org/10.1016/j.jfineco.2016.01.015

Seo, S., \& Chung, H. (2017). Capital structure and corporate reaction to negative stock return shocks. International Review of Economics and Finance, 49, 292-312. https://doi.org/10.1016/j.iref.2017.02.005

Shah, A., Shah, H., Smith, J., \& Labianca, G. (2017). Judicial efficiency and capital structure: An international study. Journal of Corporate Finance, 44, 255-274. https://doi.org/10.1016/j.jcorpfin.2017.03.012

Sorokina, N., Thornton Jr, J., \& Patel, A. (2017). Why do banks choose to finance with equity? Journal of Financial Stability, 30, 36-52. https://doi.org/10.1016/j.jfs.2017.04.002

Tao, Q., Sun, W., Zhu, Y., \& Zhang, T. (2017). Do firms have leverage targets? New evidences from mergers and acquisitions in China. North American Journal of Economics and Finance, 40(2017), 41-54. https://doi.org/10.1016/j.najef.2017.01.004

Titman, S., \& Wessels, R. (1988). The determinants of capital structure choice. The Journal of Finance, 43(1), 1-19. https://doi.org/10.1111/j.1540-6261.1988.tb02585.x

Versmissen, J., \& Zietz, J. (2017). Is there a leverage target for REITs? The Quarterly Review of Economics and Finance. https://doi.org/10.1016/j.qref.2017.01.001

Xu, Q., \& Yang, J. (2017). Real option with liquidity constraints under secondary debt illiquidity risk market. Finance Research Letters, 21(2017), 57-65. https://doi.org/10.1016/j.frl.2017.02.003

Yang, B. (2013). Dynamic capital structure with heterogeneous beliefs and market timing. Jornal of Corporate Finance, 22(2013), 254-277. https://doi.org/10.1016/j.jcorpfin.2013.05.003

Zhang, X., Yang, J., Su, H., \& Zhang, S. (2014). Liquidity premium and the Corwin-Schultz bid-ask spread estimate. China Finance Review International, 168-186. https://doi.org/10.1108/CFRI-09-2013-0121

\section{Copyrights}

Copyright for this article is retained by the author(s), with first publication rights granted to the journal.

This is an open-access article distributed under the terms and conditions of the Creative Commons Attribution license (http://creativecommons.org/licenses/by/4.0/). 